\title{
INSOLVENCY - IT’S ALL ABOUT THE MONEY
}

\section{HELEN ANDERSON*}

\section{INTRODUCTION}

Broadly speaking, there are four pots of money that matter when a company becomes insolvent. The first is the money that the failed company owes to its unsecured trade creditors - the general creditor pot. The second is the tax that is lost to federal and state revenue collectors through the non-payment of taxes including company income tax, goods and services tax (GST), Pay-As-You-Go (Withholding) tax (PAYG(W)), superannuation guarantee charge (SGC) and payroll tax - the revenue pot. The third less obvious pot is the money that the government must pay by way of safety net supports for employees unpaid by the insolvent employer, either through the Fair Entitlements Guarantee (FEG) scheme or as extra aged pensions where superannuation is lost - the safety net pot. The fourth is the money needed for enforcement, whether in the hands of ASIC, other government departments and agencies, or the liquidator - the enforcement pot. Into this fourth pot is contributed the money paid by liquidators to ASIC by way of the industry cost recovery levy.

Since the liquidator needs to be paid from the company's assets before the unsecured creditors and employees are paid, the general creditor pot, the safety net pot and the enforcement pot interact. They also interact through ASIC's contribution to enforcement via the Assetless Administration Fund's payments to liquidators, which is beneficial to the general creditor pot. Because the FEG Recovery Program (FEGRP) is now funding liquidators to recover FEG advances, the enforcement and safety net pots further interact. This is not to forget that revenue authorities at federal and state level are major creditor victims of improper behaviour at the time of insolvency, such that additional contributions to the enforcement pot can directly offset their own losses from the revenue pot. Nor does it overlook the fact that the new ASIC cost recovery levy imposed by the government on liquidators reduces the money available to liquidators in the enforcement pot and that this might impact adversely on liquidators' ability to recover assets for the benefit of the general creditor pot and the revenue pot, causing financial harm to the government.

This quick sketch is designed to illustrate the point that different types of spending and losses at the time of insolvency cannot be considered separately. They are unavoidably connected, as a result of which decisions in one area will have consequences in one or more of the other areas. The aim of this paper is to chart these connections and to make the case for greater awareness of the links between these expenditures and losses. In particular, it recommends a commitment of money to the enforcement pot, and a reallocation of that money, that will benefit not only unsecured creditors in general but also the government in multiple ways. Ultimately, the most desirable outcome from corporate insolvency is one that achieves the greatest return for all creditors including revenue authorities; minimises the cost of administering the system so that money is not pointlessly consumed; lessens reliance on government safety nets; and deters and punishes those who would use insolvency to their own advantage.

The examination of expenditure and savings in the insolvency context is particularly timely because of the ongoing debate about insolvency practitioner remuneration and their role as law enforcers and ASIC's gatekeepers, set against ASIC's role in regulating insolvency practitioners and its own role in enforcement under the Corporations Act. It is clear that 
ASIC is not a public liquidator; what is less clear is the division of enforcement responsibilities between ASIC, acting in the public interest, and the liquidator, acting in the interests of creditors. A lack of resources in the hands of liquidators, and judicial commentary about the public interest served by liquidators in taking action, ${ }^{1}$ complicates the matter. Add to that the juxtaposition of enforcement by liquidators against directors, in lieu of ASIC action, with ASIC's action against liquidators themselves for wrongdoing, especially where it involves collusion with the directors' wrongdoing.

For the sake of length and coherence, this paper concentrates on corporate, rather than personal, insolvency. Part II begins by explaining and seeking to estimate the losses and costs from the first three pots - general creditors, revenue and safety nets. Part III then considers the contentious area of enforcement, including who has the power to enforce, who has the money to enforce, and where that money comes from. Part IV brings together the previous two parts by way of analysis, integrating the understanding of the four pots of money and making recommendations for change. Part V summarises and concludes that neither spending nor revenue raising should be viewed in isolation; rather, decisions should be made based on where the money is most effectively spent and what other expenditure might be saved, or losses averted, as a result.

\section{GENERAL CREDITORS, REVENUE AND SAFETY NETS}

\section{A The General Creditor Pot}

Insolvency is inevitable for a proportion of businesses whether operated by a company or by one or more individuals. ${ }^{2}$ Since corporate insolvency by definition means that a company cannot pay all its debts as they become due, ${ }^{3}$ some creditors will not be paid when the company fails and enters some form of external administration: liquidation, voluntary administration (VA) or receivership. In general, secured creditors will recover some or all of what they are owed by realising their security. ${ }^{4}$ Next comes the priority unsecured creditors, who are provided for by s 556 of the Corporations Act. They comprise, first, the costs of the liquidation ${ }^{5}$ and after those, the entitlements of employees. ${ }^{6}$ Where employees have received some of what they are owed by their employer through an advance from FEG, ${ }^{7}$ considered further below in the safety net pot, the Department of Employment (DE) is subrogated to the employees' rights to recover as priority creditors. ${ }^{8}$ Already it becomes apparent that the amount available from the general creditor pot of money is impacted by two aspects of enforcement: the costs of liquidation and the vigorousness of recovery actions funded by DE against corporate wrongdoers.

\footnotetext{
* Professor, Melbourne Law School, University of Melbourne. The author thanks the Australian Research Council for its generous support for this research: DP140102277, 'Phoenix Activity: Regulating Fraudulent Use of the Corporate Form', and also thanks the two anonymous referees for their helpful comments.

${ }^{1}$ See cases noted below at $\mathrm{n} 69$ and accompanying text.

${ }^{2}$ For a discussion of the causes of company failure, see Rose Kenney, Gianni La Cava and David Rodgers, Reserve Bank of Australia Research Discussion Paper, 'Why Do Companies Fail', RDP 2016-09.

${ }^{3}$ Corporations Act 2001 (Cth) s 95A.

${ }^{4}$ Those holding security over a non-circulating security asset take priority over all other creditors, and those holding security over a circulating security asset take priority over unsecured creditors except for employees. Corporations Act s 561.

${ }^{5}$ Corporations Act s $556(1)(\mathrm{a})-(\mathrm{df})$.

${ }^{6}$ Ibid s 556 (1)(e) - (h).

${ }^{7}$ This is discussed below at Part IIC.

${ }^{8}$ Corporations Act s 560.
} 
At the conclusion of an external administration, the insolvency practitioner - managing controller, voluntary administrator or liquidator - sends a report, known as an EXAD report, to ASIC containing various pieces of information. ${ }^{9}$ The information in these reports is then aggregated and ASIC publishes an annual summary of their contents. ${ }^{10}$ Of significance here is the quantum of losses suffered by unsecured creditors. Returns to general creditors average 11 cents or less in $96 \%$ of cases. ${ }^{11}$ According to the latest report, '[i]n $42.7 \%$ of reports, the estimated liabilities of failed companies were $\$ 250,000$ or less, and $75.9 \%$ indicated estimated liabilities of less than $\$ 1$ million. ${ }^{12}$ In other words, $24.1 \%$ of the 8,425 reports $^{13}$ received by ASIC reported liabilities over $\$ 1$ million.

What these figures do not capture are the losses to creditors from abandoned companies, which are companies that do not enter any form of external administration. Secured creditors are likely to be unaffected here, as they typically enforce their security by way of the appointment of a receiver. However, both employees and general unsecured creditors of insolvent companies, where the directors have not sought liquidation or VA, are in a difficult position. They will need to fund the company's liquidation themselves if they hope to recover anything of what they are owed, and risk further losses if it eventuates that company has no assets. As a result, many of these creditors do nothing, and the abandoned companies are eventually deregistered by ASIC for failure to return documents or pay annual fees. ${ }^{14}$ It is estimated that there are five times as many abandoned companies as there are companies in liquidation each year, ${ }^{15}$ but the amounts lost to their creditors are unquantified.

Nonetheless, a notional allocation of the losses to creditors of abandoned companies must be added to the general creditor pot. At present, very little is done for these creditors, ${ }^{16}$ and it is arguable that money spent out of the enforcement pot addressing the issue of abandoned companies would have a beneficial impact on the general creditor pot. This issue is considered further in Part IV.

\section{B The Revenue Pot}

Unpaid taxes are very common in insolvencies, and a broad estimate of the extent of these is revealed in the EXAD reports to ASIC. For the year 2016-17, 85.5\% of insolvent companies had unpaid taxes, with $64 \%$ being between $\$ 1$ and $\$ 250,000,16.8 \%$ between $\$ 250,001$ and

\footnotetext{
${ }^{9}$ This reporting is done in compliance with ASIC, Regulatory Guide 16: External Administrators - Reporting and Lodging (July 2008) ('ASIC Regulatory Guide 16'). The form completed by the external administrator is ASIC, Form EX01: Schedule B of Regulatory Guide 16 - Report to ASIC under s422, s438D or s533 of the Corporations Act 2001 or for Statistical Purposes (13 January 2016).

${ }^{10}$ The latest is ASIC, Report 558: Insolvency Statistics - External Administrators' Reports (July 2016 to June 2017) (December 2017) ('ASIC Report 558').

${ }^{11}$ Ibid 7, table 2. In 2015-2016 and 2014-15, it was 97\% of cases, ibid. The average returns are for all forms of external administration and are likely to be even less if only liquidations were considered.

12 Ibid [87].

13 Ibid [11].

${ }^{14}$ Corporations Act s 601AB.

${ }^{15}$ Email from Adrian Brown to author, 18 March 2016, indicating that about 37,600 companies are deregistered by ASIC every year for failing to lodge documents or pay fees. (University of Melbourne Ethics ID: 1341343). This dwarfs the number of companies that enter liquidation: 6,235 companies in 2016-17: ASIC, 'Australian Insolvency Statistics: Series 1 - Companies Entering External Administration, January 1999-August 2017' (October 2017), Table 1.3. This figure has been calculated by aggregating the annual figures for '[c]ourt windup', 2,432, and '[c]reditors wind-up', 3,803, in 2016-17.

16 This is discussed further below at $\mathrm{n} 45$ and accompanying text.
} 
$\$ 1$ million, and $4.6 \%$ over $\$ 1$ million. ${ }^{17}$ That final figure alone represents 387 companies, meaning that there is at the very least $\$ 387$ million owing in unpaid taxes from these companies and probably a good deal more. Bearing in mind that these figures will not include abandoned companies, it is also instructive to look at the ATO's own data on the 'tax gap' which seeks to estimate the amount of taxes unpaid for a variety of reasons including insolvency. Three that are commonly unpaid because of insolvency are GST, PAYG(W) and superannuation. For the year 2016 - 17, they are estimated to be $\$ 4.5$ billion, $\$ 3.1$ billion and $\$ 2.85$ billion respectively. ${ }^{18}$

Superannuation is unusual in that it straddles the revenue and safety net pots, and is subject to an unusual recovery mechanism. The employer is obliged to pay at least the statutory mandated amount ${ }^{19}$ to the employee's chosen fund ${ }^{20}$ but the fund is not a creditor in the winding up. ${ }^{21}$ Superannuation not remitted to employees' nominated fund triggers a superannuation guarantee charge (SGC) liability - a tax which is collected by the ATO. ${ }^{22}$ Where the SGC is recovered, the contribution amount and interest are then remitted in due course to the employees' nominated superannuation funds. ${ }^{23}$ The revenue aspect of the SGC is a constitutional quirk ${ }^{24}$ rather than a true loss of revenue to the government. Therefore, a fuller discussion of lost superannuation is undertaken in the next section dealing with safety nets.

\section{The Safety Net Pot}

There are two relevant safety nets here, both relating to employees: FEG and the aged pension.

When a company enters liquidation, employees with unpaid entitlements are entitled to claim on the taxpayer-funded FEG, ${ }^{25}$ which covers specified amounts of wages, leave and redundancy entitlements. ${ }^{26}$ As noted above, FEG is administered by the DE, which makes the advances of these amounts, subject to various caps, to employees affected by their

\footnotetext{
${ }^{17}$ ASIC Report 558, above n 10, table 39. Note that table 26 also records external administrator reports of alleged criminal and civil breaches relating to unpaid taxes.

${ }^{18}$ https://www.ato.gov.au/About-ATO/Research-and-statistics/In-detail/Tax-gap/Australian-tax-gapsoverview/?anchor=Overview\#Overview. State taxes are also lost to insolvency and other causes, and to consider Victoria alone, its estimate of unrecoverable taxes due to insolvency in 2016-17 was \$65.7 million. Over \$30 million in unremitted payroll tax was written off during 2016-2017. See http://annualreview1617.sro.vic.gov.au/content/analysis-debt

${ }_{19}$ This amount is currently $9.5 \%$ of eligible wages.

${ }^{20}$ Superannuation Guarantee (Administration) Act 1992 (Cth) pt 3A ('SGAA'), inserted by Superannuation Legislation Amendment (Choice of Superannuation Funds) Act 2004 (Cth) sch 1 item 22.

${ }^{21}$ Superannuation is one of the entitlements which are subject to employees' statutory priority: Corporations Act s 556(1)(e)(i). The SGC enjoys that same statutory priority: s 556(1)(e)(ii).

${ }^{22}$ Difficulties in recovering this tax are examined below in Part IIIA2.

${ }^{23} S G A A$ pt 8.

${ }^{24}$ To ensure that superannuation coverage is as wide as possible, the constitutional basis of the SGC is the taxation power: Australian Constitution, s 51(ii), supported by the 'invalid and old aged pensions' power in Australian Constitution, s 51(xxiii). The taxation underpinnings of the SGC were challenged in Roy Morgan Research Pty Ltd v Commissioner of Taxation (2011) 244 CLR 97 but the majority upheld the constitutional validity of the charge, at [48].

25 Department of Employment (Cth), Fair Entitlements Guarantee <https://www.employment.gov.au/fairentitlements-guarantee-feg>.

${ }^{26}$ Under s 5 of the Fair Entitlements Guarantee Act 2012 (Cth) ('FEG Act'), an 'employment entitlement' means annual leave, long service leave, payment in lieu of notice, redundancy pay and wages.
} 
employers' 'insolvency event'. ${ }^{27}$ The DE then attempts to recoup these advances from the employer's liquidation. ${ }^{28}$ The amount of FEG paid in 2016-2017 was $\$ 186.02$ million to 12,354 claimants ${ }^{29}$ and the DE recovered $\$ 47.98$ million. ${ }^{30}$ No advances are made by FEG to employees of abandoned companies or those placed into voluntary administration. ${ }^{31}$

Nor does FEG cover superannuation. ${ }^{32}$ This may suggest that unpaid superannuation will not have financial consequences for the government, but that is not the case. The employee who has been deprived of their proper superannuation entitlements during their working life will have a greater reliance on the aged pension. In other words, denying employees access to the immediate safety net of FEG with respect to their unpaid superannuation simply increases reliance on the later safety net of the aged pension.

It is difficult to quantify both lost superannuation and the consequential additional reliance on the aged pension accurately. The ATO's superannuation tax gap was noted above, and in November 2016, a joint report was released by two super funds that estimated at least $\$ 3.6$ billion of unpaid superannuation in $2013-14 .{ }^{33}$ External administrators' reports to ASIC for the period 2016-17 show that in 2,561 administrations out of a total of 7,765 (or 33\%), employees' superannuation between $\$ 1$ and $\$ 100,000$ was unpaid. ${ }^{34}$ At the other end of the scale, there were 18 instances where over $\$ 1,000,000$ of superannuation was unpaid; there were also 164 instances of unpaid superannuation between $\$ 250,001$ and $\$ 1,000,000 .{ }^{35}$ More worrying still is the compounding effect of unremitted superannuation. Stanford has estimated that a present loss of $\$ 10,000$ will result in $\$ 57,000$ less superannuation in 30 years' time. ${ }^{36}$

This is not to suggest that every dollar unpaid in superannuation due to corporate insolvency automatically translates into the same amount of additional reliance on the aged pension. The superannuant may use some of their fund to travel or purchase a new vehicle, for instance. Nor is it suggested that all unremitted superannuation could be recovered from insolvent companies if only enforcement were improved. As with all creditors and categories of debt, it is inevitable that there will be losses. Nonetheless, these estimates of unpaid superannuation act as a reminder that at least some of the superannuation money lost to employees now will have consequences for the government in later years.

\footnotetext{
${ }^{27}$ FEG covers both companies and unincorporated employers including sole traders and partnerships: FEG Act s 5 definition of 'insolvency event'.

${ }^{28}$ Corporations Act s 560.

${ }^{29}$ Department of Employment, Annual Report 2016 - 2017, 53.

${ }^{30}$ Ibid 54. In 2015-2016, the DE recovered \$54.43million, ibid.

${ }^{31}$ FEG Act s 49(2)(a) does permit the Minister to declare that employees of companies in voluntary administration can claim where the company's liquidation is expected.

${ }^{32}$ Above $\mathrm{n} 26$ and accompanying text.

${ }^{33}$ Construction and Building Unions Superannuation and Industry Super Australia, Overdue: Time for Action on Unpaid Super (November 2016) 3.

34 ASIC Report 558, above n 10, table 37.

${ }^{35}$ Ibid. See also the supplementary submission of Industry Fund Services to the Senate ERC inquiry into superannuation non-payment, submission no 53, at 4: 'In 2015/16 the IFS insolvency team managed 9,725 cases. ... Of the insolvency cases managed by IFS $28 \%$ of cases closed returned a dividend for 23,362 members from 1,472 employers, recovering \$23.4 million.'

36 Jim Stanford, 'The Consequences of Wage Suppression for Australia's Superannuation System', Centre for Future Work, Australia Institute, September 2017, fig 2, 10.
} 
Each of the pots of money discussed above - general creditors, revenue and safety nets - are inevitably impacted upon by the extent of enforcement undertaken by those with the power, motivation, resources and information to do so. This will now be considered.

\section{ENFORCEMENT}

\section{A Who enforces and how?}

\section{ASIC and liquidators}

ASIC is required 'to strive to ... take whatever action we can, and which is necessary, to enforce and give effect to the law. ${ }^{37}$ ASIC has considerable powers in relation to corporate insolvency, such as enforcement of directors' duties breaches ${ }^{38}$ including insolvent trading, ${ }^{39}$ administrative banning provisions, ${ }^{40}$ investigative powers, ${ }^{41}$ and winding up powers. ${ }^{42}$ ASIC also has an exclusive role in enforcing criminal provisions of the Corporations Act, including strict liability offences relating to director conduct $^{43}$ as well as more serious criminal breaches. $^{44}$

In addition, since 2012, ASIC has had the power to wind up abandoned companies, but this power is exercised only for the purpose of allowing the employees of those companies to access FEG. ${ }^{45}$ By 12 September 2017, ASIC had only used its power to wind up '95 companies that owed at least 287 employees more than $\$ 5$ million in entitlements. ${ }^{46}$ This seems disproportionately small, given the many thousands of abandoned companies deregistered by ASIC annually, ${ }^{47}$ so it is questionable whether this power is exercised sufficiently to achieve its objective. ${ }^{48}$ A more likely cause of ASIC's limited involvement is the guideline that confines ASIC to cases large enough to make their costs worthwhile but not so large that that the employees could be expected to protect themselves via the appointment of a liquidator. ${ }^{49}$

\footnotetext{
37 ASIC, Annual Report 2016-2017, 14.

${ }^{38}$ Corporations Act Part 2D.1, enforceable as civil penalty breaches under Part 9.4B of the Act.

${ }^{39}$ Ibid s 588G(2), as a civil penalty breach under Part 9.4B and directly under s 588J.

${ }^{40}$ Corporations Act s 206F. In 2016 -2017, 51 people were disqualified or removed from directing companies. ASIC, Annual Report 2016-2017, 5.

${ }^{41}$ Australian Securities and Investments Commission Act 2001 (Cth) s 13.

${ }^{42}$ Corporations Act s 459A, s 462 re s 461, and s 464.

${ }^{43}$ For example, ASIC may bring action against directors for failing to provide books and records to liquidators or to assist liquidators: Corporations Act s 530A(6). In 2016-17, ASIC prosecuted 409 directors of failed companies for 723 offences of this type: ASIC, Annual Report 2016-2017, 4.

${ }^{44}$ These include criminal breaches of directors' duties under Corporations Act s 184, criminal insolvent trading under s $588 \mathrm{G}(3)$, and fraud offences such as s 596.

${ }^{45}$ Corporations Act s 489EA, which was introduced by the Corporations Amendment (Phoenixing and Other Measures) Act 2012 (Cth).

${ }^{46}$ http://asic.gov.au/about-asic/media-centre/find-a-media-release/2017-releases/17-310mr-asic-winds-up-11abandoned-companies-owing-more-than-650-000-in-employee-entitlements/.

${ }^{47}$ See above $\mathrm{n} 15$ and accompanying text.

${ }^{48}$ The Hon David Bradbury, 'Legislation Introduced to Help Workers Access Their Entitlements', Media Release No 006 (15 February 2012); See also Australian Securities and Investments Commission, ASIC's Power to Wind Up Abandoned Companies, Consultation Paper 180 (2012), [4].

49 ASIC, Regulatory Guide 242 ASIC's Power to Wind Up Abandoned Companies, January 2013, Table 1.
} 
Liquidators too have extensive powers in relation to insolvency. Pursuant to s 477(2), the liquidator exercises the company's own wide-ranging powers to bring legal proceedings ${ }^{50}$ and compromise claims. ${ }^{51}$ Amongst other things, liquidators may recover preferential payments made by the company prior to its insolvency including payments to defeat the claims of creditors, ${ }^{52}$ bring action with respect to insolvent trading, ${ }^{53}$ and examine company officers about a company's 'examinable affairs'. ${ }^{54}$ EXAD reports to ASIC also contain information about suspected offences. ${ }^{55}$ The EXAD misconduct reporting encompasses before and during the external administration process, suspected civil and criminal breaches, and whether the practitioner holds documentary evidence to support their suspicions. ${ }^{56}$ In 2016-2017, external administrators reported possible misconduct in $84.5 \%$ of reports, for a total of 18,734 alleged breaches. ${ }^{57}$

The apparent aim of this reporting ${ }^{58}$ is to enable ASIC to select those instances of wrongdoing that will generate an investigation and possible subsequent proceedings by ASIC, contributing to '(a) maintaining the integrity of the marketplace; and (b) promoting investor and consumer confidence. ${ }^{59}$ Implicit in this reporting, therefore, is the assumption that ASIC will bring at least some actions against directors and officers relating to the company's insolvency.

However, ASIC has been subject to considerable criticism in recent years over its performance ${ }^{60}$ and lack of responsiveness to complaints about wrongdoing, ${ }^{61}$ and the sharing of power and responsibilities between ASIC and liquidators appears to have led to tension between the two. It is possible that the highly improper behaviour of liquidators such as Stuart Ariff, which triggered criticism of ASIC's inaction and the 2010 Senate Inquiry into the Insolvency Industry, ${ }^{62}$ has damaged relationships between the two parties. ${ }^{63}$ Both would like to see the other do more. Although there is little detail as to precisely what ASIC expects

\footnotetext{
${ }^{50}$ Corporations Act s 477(2)(a).

${ }^{51}$ Ibid s 477(1)(d). A compensation order can be granted for breach of civil penalty provisions under Corporations Act s $1317 \mathrm{H}$.

${ }^{52}$ Ibid pt 5.7B. See for example, Featherstone v Ashala Model Agency Pty Ltd (in liq) \& Anor [2017] QCA 260, where the Queensland Court of Appeal considered that s 588FE(5) allowed the recovery of payments made to defeat creditors in an apparent phoenix transaction. The payments had been made five years prior to the company's eventual liquidation.

${ }^{53}$ Corporations Act s 588M.

${ }^{54}$ Ibid pt 5.9 div 1. Liquidators are 'eligible applicants' as defined in s 9 of the Act.

${ }^{55}$ Above $\mathrm{n} 9$ and accompanying text.

${ }^{56}$ ASIC Regulatory Guide 16, above n 9.

${ }^{57}$ ASIC Report 558, above n 10, [41].

${ }^{58}$ ASIC Regulatory Guide 16, above n 9, [RG16:4(c)]. See also [RG 16.122] regarding documentary evidence and the substantiation of allegations of wrongdoing.

${ }^{59}$ Ibid [RG16.5].

${ }^{60}$ See the lengthy debate on the issue in Senate Economics References Committee, Performance of the Australian Securities and Investments Commission, June 2014 (Senate ERC, Performance of ASIC), chap 15 and 16.

${ }^{61}$ Australian Government, Fit For the Future: A Capability Review of the Australian Securities and Investments Commission - A Report to Government, Australian Government, Canberra, December 2015.

${ }^{62}$ Senate Economics References Committee, Parliament of Australia, The Regulation, Registration and Remuneration of Insolvency Practitioners in Australia: the Case for a New Framework. (September 2010), Canberra

${ }^{63}$ Note that registered liquidators who are members of a professional association such as ARITA are subject to a code of professional practice, breach of which renders them subject to disciplinary proceedings including termination of their membership. The Insolvency Law Reform Act 2016 (Cth) inserted sch 2 into the Corporations Act and now contains extensive new provisions including with regards to the registration of liquidators, their remuneration and disciplinary proceedings against them.
} 
of liquidators in terms of enforcement, ${ }^{64}$ ASIC publications and statements make clear that liquidators are to play a vital role as one of ASIC's 'gatekeepers'. ${ }^{65}$ ASIC's own limited role is reflected in its published enforcement policy, which speaks of ensuring that 'we direct our finite resources appropriately'. ${ }^{66}$ In 2012, then ASIC Chairman Greg Medcraft said:

ASIC is not a prudential regulator, not a conduct and surveillance regulator. The system we have is based on gatekeepers doing the right thing and it is self-executing. It is quite important in understanding what we are currently resourced to do. We are not resourced to be looking at everybody, and that is a very important message. ${ }^{67}$

Therefore it would appear that liquidators are expected to do much of the enforcing themselves. However, the Corporations Act expressly confirms that liquidators are under no obligation to conduct any investigations beyond the bare minimum required for the statutory report. ${ }^{68}$ While liquidators have powers to bring actions, they have no legal duty to do so. ${ }^{69}$ The professional body representing registered liquidators, the Australian Restructuring Insolvency and Turnaround Association (ARITA) noted in its submission to the Productivity Commission Inquiry into Business Set-up, Transfer and Closure ${ }^{70}$ that court ordered liquidations cost liquidators $\$ 40$ million in unpaid time and expenses. In its submission to the 2014 Insolvency Law Reform Bill, ARITA stated that

it is not reasonable for a practitioner to attend to tasks if there are no funds from which they will be remunerated, or for which no security can be taken. However if the law is to require practitioners to undertake work for which they cannot be paid it should clearly say so. ${ }^{71}$

\section{The ATO}

The ATO simply ranks as a non-priority unsecured creditor in a liquidation distribution but it has some unique or enhanced creditor powers, in addition to its regulatory powers, that make it a formidable enforcement agency. These extra powers are justified due to its responsibility to protect the revenue but there is also a suggestion that general creditors benefit from the efforts of the ATO. ${ }^{72}$ Indeed, external administrators may refer instances of suspected

\footnotetext{
${ }^{64}$ For example, in the ASIC Corporate Plan 2017-18 to 2020-2021, Focus 2017-2018, ASIC presents 'what good looks like' for insolvency practitioners: 'Registered liquidators: act independently and competently; ensure cost-effective, timely and appropriate outcomes; [and] perform their role in accordance with proper standards of professional conduct' at 7 .

${ }^{65}$ ASIC, Annual Report 2016-2017, [3.2.2]. Also, Treasury (Cth), Proposed Industry Funding Model for the Australian Securities and Investments Commission: Consultation Paper (28 August 2015), 49

${ }^{66}$ ASIC, Information Sheet 151: ASIC's approach to enforcement, 20 February 2012, 3.

${ }^{67} \mathrm{Mr}$ Greg Medcraft, Chairman, Australian Securities and Investments Commission, Committee Hansard, 12 September 2012, 15, quoted in Parliamentary Joint Committee on Corporations and Financial Services, Statutory Oversight of the Australian Securities and Investments Commission: the role of gatekeepers in Australia's financial services system, July 2013. From 1 February 2018, the ASIC chair is James Shipton.

${ }^{68}$ Corporations Act s 545.

${ }^{69}$ Note the recognition of the public interest role of liquidators in bringing litigation in Hall v Poolman (2009) 75 NSWLR 99, [128] - [129]; Sanderson as Liquidator of Sakr Nominees Pty Ltd (in liquidation) v Sakr [2017] NSWCA 38, [58].

${ }^{70}$ Australian Restructuring Insolvency and Turnaround Association (ARITA), Submission No 31 to Productivity Commission, Inquiry into Business Set-up, Transfer and Closure, 2 March 2015 at http://www.pc.gov.au/_data/assets/pdf file/0007/187387/sub031-business.pdf, 30; Productivity Commission, Business Set-up, Transfer and Closure Final Report (2015), 15.

${ }^{71}$ ARITA, Submission to Treasury, Insolvency Law Reform Bill 2014, 18 December 2014 at [3.5].

${ }^{72}$ Inspector General of Taxation, Debt Collection: A Report to the Assistant Treasurer (July 2015), [2.84] 'In taking debt recovery actions, certain stakeholders have advised that creditors often rely on the ATO to take quick and appropriate action in relation to insolvent taxpayers.'
} 
misconduct to the ATO. ${ }^{73}$ It makes sense therefore to recognise and encourage the ATO's capacity to detect insolvency wrongdoing and to act against it.

In its capacity as a creditor, the ATO can apply for the winding up of non-compliant companies, as other creditors can do, but with some enhanced powers. Unlike the debts owed to general creditors, ${ }^{74}$ the ATO's debt may be an estimate of liability, ${ }^{75}$ and the statutory demand is conclusive proof that the debt is owed. ${ }^{76}$ According to the ATO's $2016-2017$ annual report, '[d]ebt-related legal action for creditors' petitions and company wind-ups decreased from 4,801 cases in 2015-16 to 2,952 cases in 2016-17'. ${ }^{77}$ The ATO can also apply for companies to be wound up on the just and equitable ground, ${ }^{78}$ may apply to set aside a deed of company arrangement, ${ }^{79}$ or apply to have the company's assets frozen to prevent dissipation. ${ }^{80}$

The unique powers the ATO exercises as a creditor ${ }^{81}$ have the ability to act as a deterrent against wrongdoing, even if there is no flow-on benefit to general creditors in terms of their own recovery. For example, the ATO can issue garnishee notices that enable it to recover money held in third party hands which is owed to the debtor. ${ }^{82}$ The ATO may seek a security bond from a taxpayer who they suspect will later default on payment. ${ }^{83}$ In addition, the ATO may issue a director of a company in default of its PAYG(W) and superannuation obligations with a director penalty notice (DPN) requiring them to place the company promptly into external administration, in the absence of which they will be personally liable for the tax debt. $^{84}$

As a regulator, the ATO can obtain information which it is able to use in its recovery actions as a creditor. ${ }^{85}$ For example, it has specific powers to obtain access to books and records ${ }^{86}$ and conduct oral examinations. ${ }^{87}$ The ATO may also refer companies and individuals for prosecution with respect to a range of criminal offences relating to the company's insolvency,

\footnotetext{
73 ASIC Report 558, above n 10, [78]. For reports in 2016-17 where external administrators reported possible misconduct, 167 indicated the external administrator had referred, or was intending to refer, the matter to another authority. The three highest number of referrals to other authorities were to the Australian Taxation Office (105 reports), state or territory police (18 reports) and Fair Trading/Consumer Affairs (18 reports).

${ }^{74}$ Corporations Act s 459E(2) and (3).

${ }^{75}$ Ibid s 459E(5). Ability to make estimates: Income Tax Assessment Act 1936 (Cth) ('ITAA36') pt VI div 8; Taxation Administration Act 1953 (Cth) ('TAA') sch 1, div 268.

${ }^{76}$ TAA sch 1, s 105-100; TAA s 14ZZM and 14ZZR.

77 Australian Taxation Office, Annual Report 2016-2017, 213.

${ }^{78}$ Corporations Act s 461(1)(k). See, for example, Deputy Commissioner of Taxation v Casualife Furniture International Pty Ltd [2004] VSC 157.

${ }^{79}$ Corporations Act 447A. See for example, Deputy Commissioner of Taxation v Woodings (1994) 13 WAR 189.

${ }^{80}$ See for example, Deputy Commissioner of Taxation v Gashi [2010] VSC 120 where an order was made under Order 37A of the Supreme Court (General Civil Procedure) Rules.

${ }^{81}$ Note also the ATO's privileged position in relation to appeals and AAT reviews: TAA s 14ZZMR and s 14ZZM respectively: also, the ATO's ability to recover against liquidators and receivers: eg TAA sch 1, ss 26045, 260-75.

${ }^{82}$ TAA sch $1, \mathrm{~s} 260-5(2)$.

${ }^{83}$ Ibid s 255-100.

${ }^{84}$ Ibid s 269-15.

${ }^{85}$ See further Sylvia Villios, 'Tax Collection, Recovery and Enforcement Issues for Insolvent Entities' (2016) 31 Australian Tax Forum 425; Sylvia Villios, 'Director penalty notices - promoting a culture of good corporate governance and of successful corporate rescue post insolvency,' (2016) 25(1) Revenue Law Journal Article 2.

${ }^{86}$ Ibid s 353-10.

${ }^{87}$ Ibid s 353-10.
} 
including fraud ${ }^{88}$ defrauding the Commonwealth, ${ }^{89}$ and false or misleading statements or record keeping failures. ${ }^{90}$ This is not to suggest that all criminal tax provisions can be utilised. Some are unsuited to insolvency, such as those that require a scheme to avoid incurring a tax liability rather than the actual payment of tax properly incurred. ${ }^{91}$

Curiously, the Crimes (Taxation Offences) Act 1980 (Cth) (CTOA), ${ }^{92}$ which was introduced following 'Bottom of the Harbour' tax evasion in the $1970 \mathrm{~s},{ }^{93}$ does not appear to be utilised by the ATO. It imposes criminal sanctions where a person enters into an arrangement with the intention of securing that a company will be unable to pay income tax or a range of other taxes including the superannuation guarantee charge. ${ }^{94}$ The penalties are 10 years imprisonment or 1,000 penalty units or both. This would seem to capture the types of improper arrangements entered into around the time of insolvency that result in less money going into the revenue pot.

While the enforcement of superannuation comes through the superannuation guarantee charge which is administered by the ATO,${ }^{95}$ the ATO relies on the employer to self-declare their failure to pay. ${ }^{96}$ Alternatively, an ATO investigation may be prompted by employee complaints ${ }^{97}$ that superannuation has not been paid. However, for a variety of reasons, the ATO may not initiate recovery action or may be unable to recover the outstanding amount. ${ }^{98}$ Indeed, the employee may be unaware of the non-payment until the employer company becomes insolvent. ${ }^{99}$ The director of a non-compliant employer company may be personally liable for the company's unremitted superannuation via a director penalty notice (DPN) but as noted above, the director may avoid that liability by promptly placing the company into liquidation or VA. In consequence, neither the SGC liability on the insolvent employer company, nor the DPN on the director will necessarily result in the employee's superannuation being paid, increasing reliance on the safety net pot through additional dependence on the aged pension.

\section{The Fair Work Ombudsman}

While superannuation is enforceable by the FWO where it is provided for under modern awards and enterprise agreements, there is a tendency for the FWO to refer complaints to the

${ }^{88}$ Criminal Code Act 1995 (Cth) sch, s 135.1 (fraud); s 135.4 (conspiracy to defraud).

${ }^{89}$ Crimes Act 1914 (Cth) s 29D.

${ }^{90}$ TAA ss $8 \mathrm{~K}$ and s $8 \mathrm{~L}$.

${ }^{91}$ See for example, the general anti-avoidance rule (GAAR): ITAA36 s177D; the promoter penalty regime: TAA sch 1, div 290. Because the company has committed no offence by simply not remitting their properly incurred tax, accessory liability pursuant to TAA s $8 \mathrm{Y}$ is ineffective, as are reparation orders under Crimes Act $1914 \mathrm{~s}$ 21B. The court can only order a person to make reparation for any Commonwealth loss where there is a tax offence.

${ }^{92}$ Crimes (Taxation Offences) Act 1980 (Cth) ('CTOA'); s 5 (arrangements to avoid payment of tax); s 6 (accessory liability for arrangements to avoid payment of tax).

${ }^{93}$ See Peter Grabowsky, 'Wayward governance : illegality and its control in the public sector' (Australian Institute of Criminology, 1989) ch 9.

${ }^{94}$ CTOA ss 5, 17. See also Lidia Xynas, 'Tax Planning, Avoidance and Evasion in Australia 1970-2010: The Regulatory Responses and Taxpayer Compliance' (2011) 20(1) Revenue Law Journal 1.

${ }^{95}$ Superannuation Guarantee Charge Act 1992 (Cth).

${ }^{96}$ SGAA ss 46, 64A.

${ }^{97}$ ATO, Unpaid Super <https://www.ato.gov.au/Individuals/Super/In-detail/Growing/Unpaid-super/> .

${ }^{98}$ ATO, Questions You May Have About this Step in the Process <https://www.ato.gov.au/Individuals/Super/Indetail/Growing/Unpaid-super/?page=4>.

${ }^{99}$ See Helen Anderson and Tess Hardy, 'Who Should be the Super Police? Detection and Recovery of Unremitted Superannuation’ (2014) 37 UNSW Law Journal 162. 
ATO for enforcement action. ${ }^{100}$ As noted above, this will not necessarily result in recovery for the employee's benefit. In one particularly egregious instance involving numerous vulnerable cleaning company employees where action was brought by the FWO for underpayments of entitlements including superannuation, the FWO did not seek compensation with respect to unpaid superannuation even though the court was willing to impose penalties with respect to those breaches. ${ }^{101}$ This approach is regrettable because the tools available to the FWO - strict liability on companies for employee entitlements pursuant to modern awards and enterprise agreements, ${ }^{102}$ coupled with accessory liability for those 'knowingly concerned' in the company's breach ${ }^{103}$ - are extremely potent with respect to unpaid entitlements in insolvency and are arguably superior to those of the ATO. Liability is not dependent upon wrongdoing and is not defeated, in the case of the accessory's liability, by the company's insolvency. Directors, particularly of small companies, and advisors are highly likely to be caught here and can be made jointly liable to pay the amount ordered against the company. ${ }^{104}$

In addition, the government has been active in improving recovery mechanisms in the wake of scandals involving companies such as 7-Eleven and Baiada. ${ }^{105}$ These have led to the passage of the Fair Work Amendment (Protecting Vulnerable Workers) Act 2017 (Cth) which, inter alia, provides for liability on holding companies and franchisors for the contraventions of subsidiaries and franchisees respectively, where reasonable steps had not been taken to prevent the contravention. ${ }^{106}$ This allows access to the potentially deeper pockets of those who pull the strings of insolvent employer companies. Use of these provisions by the FWO could vastly improve recovery of unremitted superannuation in addition to other unpaid employee entitlements.

\section{B Funding for Enforcement}

Both the ATO and FWO are funded by the government to undertake the full range of their responsibilities, including insolvency-related enforcement. Because this funding is uncontroversial, it will not be considered further here. Rather, the discussion concentrates on the 'tug of war' between ASIC and liquidators.

\section{ASIC}

ASIC generates revenue from both its registry services and from those who pay to search those registers. According to the ASIC Annual Report for 2016-2017, it raised $\$ 920$ million

\footnotetext{
${ }^{100}$ Mr Michael Campbell, Deputy Fair Work Ombudsman, Operations, Fair Work Ombudsman, Proof Committee Hansard, 3 March 2017, 39: 'In simple terms, the work we [as the FWO] focus on is that which is clearly within our jurisdiction. The ATO has a broader jurisdiction than ours. It reaches more employees and employers and it has a better toolkit and set of powers to seek out and recover unpaid superannuation. So we refer it to them and we think that is an appropriate approach'. In 2015-2016, the FWO made 2,405 referrals to the ATO: Australian Taxation Office, Submission No 6 to Senate Economics References Committee, Inquiry into Superannuation Guarantee Non-payment, 2016-17, [53].

${ }^{101}$ Fair Work Ombudsman v Grouped Property Services Pty Ltd (No 2) [2017] FCA 557, [115], [151], [496], and [507].

102 Fair Work Act 2009 (Cth) s 45 and s 50 respectively.

${ }^{103}$ Ibid s 550.

${ }^{104}$ See, for example, Fair Work Ombudsman v Step Ahead Security Services \& Anor [2016] FCCA 1482, [80].

${ }^{105}$ Explanatory Memorandum, Fair Work Amendment (Protecting Vulnerable Workers) Bill 2017 (Cth), 1.

${ }^{106}$ Fair Work Act 2009 (Cth) div 4A.
} 
in fees and charges that financial year. However, ASIC does not retain these funds; rather, they are paid into consolidated revenue and ASIC is then funded via a budgetary appropriation. This was $\$ 342$ million with some additional special purposes funding. ${ }^{107}$ Penalties imposed administratively and by courts are paid into consolidated revenue rather than into ASIC's purse. ASIC also raises money from the industry cost recovery levy, which is considered further in Part IIIC below. In 2014, the government announced that it would conduct a scoping study on the privatisation of the ASIC Registry business. ${ }^{108}$ This initiative was motivated primarily as a means of overcoming the information technology limitations within ASIC by placing the registry in private hands. The government later decided not to proceed with the proposal. ${ }^{109}$

Clearly, ASIC's allocation from consolidated revenue is intended to cover all of its operations, not just those involving insolvency, less still enforcement in the insolvency context. The amounts allocated to insolvency enforcement are considered below in the discussion concerning the industry cost recovery levy.

\section{Liquidators}

\section{(a) What liquidators are paid}

As noted in Part II, liquidators are paid as the top priority unsecured creditors in the distribution of a company's assets in its liquidation. ${ }^{110}$ However, this does not mean that liquidators can charge whatever they like. Schedule 2, division 60 of the Corporations Act, inserted by the Insolvency Law Reform Act 2016 (ILRA), ${ }^{111}$ provides for a liquidator remuneration determination to be made by members in a members' voluntary winding up or by creditors or a committee of inspection in a creditors' winding up. ${ }^{12}$ In the absence of a remuneration determination, liquidators receive $\$ 5,000 .{ }^{113}$

Liquidator remuneration is a particular concern of ASIC's. ${ }^{114}$ The issues came to a head in Sanderson as Liquidator of Sakr Nominees Pty Ltd (in liquidation) $v$ Sakr, ${ }^{115}$ a decision of the New South Wales Court of Appeal, following a decision by Brereton J cutting a liquidator's remuneration. ${ }^{116}$ Because the creditors had already been paid out in full, the liquidator required court approval of his final remuneration. ${ }^{117}$ In simple terms, the issue at stake was whether the liquidator's remuneration should be proportional to the amount of the company's assets - known as ad valorem, or whether the liquidator was entitled to be paid for the work actually done at the firm's standard rates - referred to as 'time-based remuneration'.118

\footnotetext{
107 ASIC, Annual Report 2016-2017, [1.6.2] - [1.6.3]. The government provided ASIC with an additional \$61.1 million over four years to enhance its data management and analysis capabilities. At 6 .

${ }^{108}$ It was described as 'market testing for private sector interest to upgrade, operate and add value to the ASIC Registry'. See http://www.finance.gov.au/procurement/scoping-studies/asic-faqs/

109 Ibid.

${ }^{110}$ Above n 5.

${ }^{111}$ For some of the history behind this legislation, see Australian Government, Treasury, Proposals Paper: A Modernisation and Harmonisation of the Regulatory Framework applying to Insolvency Practitioners in Australia (December 2011).

${ }^{112}$ Corporations Act, sch 2, s 60-10

${ }^{113}$ Ibid s 60-1.

${ }^{114}$ See, for example, Templeton v Australian Securities and Investments Commission [2015] FCAFC 137.

115 [2017] NSWCA 38.

${ }^{116}$ In the matter of Sakr Nominees Pty Ltd [2016] NSWSC 709.

117 The remuneration determination by the court was under Corporations Act s 473(3)(b)(ii) as it then was, prior to the passage of the remuneration provisions in the ILRA noted above.

${ }^{118}$ The relevant factors for the court to consider were set out at Corporations Act s473(10).
} 
Brereton $\mathrm{J}$ had considered that ad valorem remuneration acts as a disincentive to the disproportionate expenditure of time. ${ }^{119}$ ASIC made a submission to the court in support of the primary judge's approach, following which ARITA appeared amicus curiae to support payment for 'necessary work, properly performed'. ${ }^{120}$

The Court of Appeal rejected the suggestion that ad valorem was appropriate to all liquidations, because it disregarded the factors for court consideration itemised in then $s$ 473(10). ${ }^{121}$ For the same reason, purely time based remuneration was also rejected. ${ }^{122}$ Significantly, the court confirmed that liquidators are entitled to be remunerated for their work which does nothing to augment funds for creditor distribution, such as statutory reporting work, ${ }^{123}$ and for work unsuccessfully attempting to recovery assets. ${ }^{124}$ A subsequent court confirmed that the liquidator's work with respect to Sakr Nominees was reasonably necessary. ${ }^{125}$

(b) Assignment of rights and litigation funding

Following the example of both the $\mathrm{UK}^{126}$ and New Zealand, ${ }^{127}$ the ILRA has given insolvency practitioners the power assign any right to sue that is conferred on them by the Corporations Act, ${ }^{128}$ subject to a number of limitations: first, the external administrator must give written notice to the creditors before assigning any right; and second, the external administrator must seek court approval to assign the right if the relevant action has already been commenced. ${ }^{129}$ Prior to the passage of the ILRA, the liquidator could not assign unfair preference claims but could assign claims for breach of duty. ${ }^{130}$

In addition, liquidators can seek litigation funding for claims including unfair preferences where they are of the opinion that the recovery will be sufficient to justify the litigation. This is particularly useful where the company's assets have been improperly removed, resulting in there being a lack of available money within the company to otherwise fund their action. The power to assign rights would allow the liquidator to step out of the action entirely, leaving the funder as assignee to complete the litigation or otherwise settle the claim.

\section{(c) Government assistance for liquidators}

There are two sources of government assistance for liquidators: the Assetless Administration Fund (AAF) available from ASIC since 2006, and the FEG recovery program (FEGRP), available from the DE since 2015. ${ }^{131}$

\footnotetext{
${ }^{119}$ In the matter of Sakr Nominees Pty Ltd [2016] NSWSC 709, [16].

${ }^{120}$ See

http://www.arita.com.au/imis_prod/ARITA/News/ARITA_News/Major_victory_for_reasonable_and_proper_li quidator_remuneration.aspx

${ }^{121}$ [2017] NSWCA 38, [52].

122 Ibid [60].

123 Ibid [57].

124 Ibid [58].

125 In the matter of Sakr Nominees Pty Ltd [2017] NSWSC 668, [27].

${ }^{126}$ Insolvency Act 1986 (UK) s 246ZC and ZD, introduced by Small Business, Enterprise and Employment Act 2015 (UK) s 118.

${ }^{127}$ Companies Act 1993 (NZ) s 260A(1).

${ }^{128}$ Corporations Act sch 2, s 100-5(1).

${ }^{129}$ Ibid s 100-5(2) and (3) respectively.

${ }^{130}$ Re Cant; Re Novaline Pty Ltd (in liq) (2011) 282 ALR 49.

${ }^{131}$ After an initial pilot program, the FEG Recovery Program has become ongoing since 1 January 2017 :

https://www.employment.gov.au/feg-recovery-program
} 
The AAF was a recommendation of the Stocktake Report in $2004 .^{132}$ It is a fund provided by the government to finance insolvency practitioners in their work on behalf of companies with few or no assets. The aim of the fund is to overcome the inability of liquidators to make proper investigations due to financial constraints, ${ }^{133}$ primarily to enable ASIC to bring enforcement action. ${ }^{134}$ AAF funding is available for investigations where s 206F director banning proceedings may be appropriate, ${ }^{135}$ or where court proceedings for serious misconduct pursuant to the Corporations Act may be warranted. ${ }^{136}$ Since 2012, applications for funding for the recovery of assets have been allowed subject to constraints where fraudulent or unlawful phoenix activity is suspected. ${ }^{137}$ However, there have been criticisms of the manner in which AAF is available and the amounts payable. ${ }^{138}$

The DE's FEGRP is funding liquidators to bring actions on their behalf as a subrogated creditor against company directors and others to recoup FEG payments made to employees. This creates the possibility that both FEG as the subrogated priority creditor as well as lower ranking unsecured creditors will recover what they are owed, if the liquidators are very successful in their efforts. In addition, the FEGRP sends the government's message of deterrence against exploitation of taxpayer funds advanced by the FEG. In some instances, such as with Queensland Nickel, the Department of Employment has successfully applied for the appointment of its own special purpose liquidator to protect its position. ${ }^{139}$

Nonetheless, while ensuring that liquidators are funded to pursue recovery of assets on behalf of creditors, as well as to bring actions against wrongdoers in appropriate circumstances, it is important to acknowledge that liquidators themselves may be involved in wrongdoing. ${ }^{140}$ This necessitates regulation and supervision by ASIC, with compliance proceedings being required in some circumstances. Liquidators have now become subject to a cost recovery levy, which is discussed in the next section.

\section{The ASIC cost recovery levy and industry funding model}

The cost recovery levy commencing in 2017 is not targeted solely at liquidators as a regulated population. Its genesis was a recommendation of the Final Report of the Financial System Inquiry, which recommended the adoption of an industry funding model, as had the

\footnotetext{
${ }^{132}$ Parliamentary Joint Committee on Corporations and Financial Services, Corporate Insolvency Laws: A Stocktake, 2004, recommendation 28 at [7.50]. The Stocktake Report found assetless administrations 'one of the more difficult, longstanding and important issues that it had to consider': at [7.43].

133 ASIC, Assetless Administration Fund: Funding Criteria and Guidelines, Regulatory Guide 109 (November 2012), [RG109.1].

${ }^{134}$ Ibid [109.5]-[109.8].

135 According to ASIC, Annual Report 2016-2017, 186, ASIC received 562 banning applications under the AAF scheme. They resulted in 34 out of 36 bannings made by ASIC during that period.

${ }^{136}$ ASIC Regulatory Guide, above n 133, [RG109.26].

${ }^{137}$ Ibid Part E.

${ }^{138}$ For example, ARITA submitted that insolvency practitioners 'report that funding may be difficult to obtain and doesn't fully remunerate for the work involved' (sub. 31, p. 30). This was noted in Productivity Commission Business Set Up, above n 70, 410-411.

139 This application was granted by Dowsett $\mathrm{J}$ in the Federal Court on $18^{\text {th }}$ May 2016 (unreported). PPB Advisory will be attempting to recover approximately $\$ 69$ million paid by FEG towards Queensland Nickel workers' entitlements.

${ }^{140}$ See above n 62 and accompanying text; also, for example, Australian Securities and Investments Commission v Dunner [2013] FCA 872.
} 
earlier Senate Economics Committee's review of ASIC's performance. ${ }^{141}$ The justifications for the levy are ensuring that costs are borne by those creating the need for regulation, not the general public via taxation, ${ }^{142}$ establishing price signals about resource allocations within ASIC, creating more incentives for self-regulation and improvement of behaviour, and improving cost transparency and accountability to industry. ${ }^{143}$ ASIC has stated that the ultimate rationale was 'greater stability and certainty in our funding, ... to ensure that we are adequately resourced to carry out our regulatory mandate'. ${ }^{144}$

These justifications are hard to reconcile. The creation of price signals is intended to deter the sorts of behaviours that require regulatory intervention. In other words, better behaviour will result in a lower levy. It is unclear how this would translate into greater certainty about ASIC's funding. If the levy works as intended, the behavioural responses to those price signals will vary the amount of levy that is raised. This leads to funding uncertainty rather than the opposite. It also seems somewhat disingenuous to suggest that ASIC's funding is either unstable or uncertain. For an organisation which plays such a key role in corporate and financial services regulation and which provides such a significant dividend to the government each year, it is difficult to imagine that the government's funding of ASIC is under threat.

Even if the justifications are sustainable in relation to other populations regulated by ASIC, there are objections that can be made to imposing the levy on liquidators. ASIC has claimed that by imposing the levy only on those who need regulation by ASIC, 'general taxpayers, many of whom do not use or benefit directly from some of ASIC's regulatory activities, are not burdened with these costs. ${ }^{145}$ However, this approach fails to recognise that liquidators, playing a gatekeeper role for the government, assist ASIC with its own work as a corporate regulator, and that the general public benefits from the contribution made by liquidators. This is not the case with any of the other regulate populations, ${ }^{146}$ nor is the work done by liquidators as detectives and reporters of insolvency related corporate wrongdoing mirrored by any other profession.

The currently proposed calculation of the levy is also concerning. The focus of ASIC's concern about liquidators is 'independence (especially the adequacy of disclosure in declarations of relevant relationships), remuneration disclosure, and disrupting the activities of professional facilitators (including pre-insolvency advisers). ${ }^{147}$ Primarily, these sorts of issues occur in the liquidations of small proprietary companies, where there is poor

\footnotetext{
${ }^{141}$ Australian Government, Proposed Industry Funding Model for the Australian Securities and Investments Commission, Consultation Paper, 28 August 2015, 1.

${ }^{142}$ Australian Government, Proposed Industry Funding Model for the Australian Securities and Investments Commission, Proposals Paper, November 2016, 5.

${ }^{143}$ ASIC, Cost Recovery Implementation Statement: Levies for ASIC Industry Funding (2017-18), October $2017,5,7$.

${ }^{144}$ Ibid [9].

${ }^{145}$ Australian Securities and Investments Commission, Treasury consultation paper: Proposed industry funding model for the Australian Securities And Investments Commission', Submission by ASIC, October 2015, [17 (a)].

146 The full list of regulated populations subject to the levy is contained in ASIC, Report 535 ASIC Cost Recovery Arrangements: 2017-2018, July 2017, Appendix. These include companies of different types and sizes, credit providers, margin lenders, superannuation trustees, securities exchange operators, credit ratings agencies and financial services licensees.

${ }^{147}$ ASIC, 'Proposed Industry Funding Model for ASIC: Supporting Attachment to the Government's Proposals Paper’ (November 2016) [107].
} 
transparency of the arrangements surrounding the winding up of the companies. ${ }^{148}$ However, the total levy on the $2,409,919$ small proprietary companies is to be $\$ 7,548,000$, or about $\$ 3.13$ per company. ${ }^{149}$ In contrast, 711 registered liquidators will bear levies totalling $\$ 10,196,000$, or $\$ 14,340$ per liquidator. ${ }^{150}$

Quite apart from the quantum of the levy, the liquidator levy is misconceived for three other reasons. First, as noted above, there are vastly more companies abandoned each year than there are companies placed into liquidation. A levy on liquidators does nothing to tackle the abandoned company issue. Second, not all pre-insolvency advisors are registered liquidators and some of the most notorious examples are in fact lawyers, accountants and other 'business advisors'. ${ }^{151}$ This contradicts one of the main justifications of the levy, that 'the costs of the regulatory activities undertaken by ASIC are borne by those creating the need for regulation'. ${ }^{152}$

Finally, every dollar liquidators pay to ASIC by way of the levy is one dollar less spent on doing their jobs properly or one dollar less for non-priority unsecured creditors, including the government itself. Unlike the other professions and categories of regulated person covered by ASIC's cost recovery levy, every client of a liquidator is insolvent. Any additional impost on liquidators necessarily must be passed on to their paying clients - insolvent companies with some assets - and exacerbates the cross-subsidisation ${ }^{153}$ that already occurs for assetless administrations. In essence, a levy on liquidators for ASIC's services will be borne by the creditors of companies which enter liquidation with assets. However, the capacity of liquidators to cross-subsidise assetless liquidations from those with some money is increasingly untenable because of the heavy focus of ASIC scrutinising liquidator remuneration as evidenced by $S a k r$ above.

\section{ANALYSIS}

\section{A Bringing the Money Pots Together}

It is inevitable that corporate insolvency will cause financial losses for some creditors, government and society as a whole. Nonetheless recognising the connections between the four pots of money discussed above has the capacity to minimise those losses. Focusing on minimising what is spent from the enforcement pot, rather than what could be saved in the general creditor, safety net and revenue pots, is fundamentally unsound. For example, ASIC's emphasis on enforcement through gatekeepers has the unfortunate consequence of ignoring the issue of abandoned companies where there is no external administrator appointed. No-one

\footnotetext{
${ }^{148}$ Small proprietary companies are defined as those with two out of the following three characteristics: consolidated revenue of less than $\$ 25$ million, consolidated gross assets of less than $\$ 12.5$ million and less than 50 employees: Corporations Act s $45 \mathrm{~A}(2)$.

${ }^{149}$ Above n 143, [93]. This includes $\$ 455,000$ for surveillance, or 18.9 cents per company, and $\$ 4.511$ million, or $\$ 1.87$ per company, on enforcement.

${ }^{150}$ Ibid [109].

${ }^{151}$ See, for example, Timothy Somerville, a solicitor found to be an accessory to multiple directors' duty breaches: ASIC v Somerville \& Ors [2009] NSWSC 934. Also Phillip Whiteman, raided by both ASIC and the ATO, who ran AHW Solicitors, A\&S Services, Bolton \& Swan Solicitors, and DNV Accountants. See further http://asic.gov.au/about-asic/media-centre/find-a-media-release/2015-releases/15-031mr-gold-coast-charteredaccountant-sentenced-following-asic-investigation/; https://www.ato.gov.au/Media-centre/Articles/Mediareleases/Phoenix-Taskforce-swoops-on-pre-insolvency-industry/

${ }^{152}$ Above $\mathrm{n} 142$ and accompanying text.

${ }^{153}$ Note the comments of Brereton J in In the matter of Dungowan Manly Pty Limited [2016] NSWSC 1346, [12].
} 
is there to detect wrongdoing, bring enforcement action and recover assets for creditors. Because these losses to the general creditor pot are by their very nature unquantifiable, they are overlooked. But the economic fallout exists nonetheless.

There are other less visible costs. Poor liquidator morale and feelings of disenfranchisement are to be expected where both government, via new legislation such as the ILRA, and ASIC, via their pronouncements and submissions in Sakr, demonstrate a distrust for liquidators. These sentiments translate into dysfunctional relations between the various parties, and could result in liquidators adopting a 'work to rule' mentality that sees them doing little beyond the bare minimum. Such an attitude might reduce liquidator costs in terms of the enforcement pot but will have consequences on recoveries into the general creditors and revenue pots. Less vigilance by liquidators could easily result in more misbehaviour by directors. More liquidators could be tempted to give improper pre-insolvency advice. Each of these has consequences for other pots. Proper liquidator funding can save money, not just cost money.

It is instructive to note that the arguments in favour of an ad valorem approach by Brereton $\mathrm{J}$ in $S a k r$ related to small liquidations where liquidators would recover comparatively little for their efforts. No-one appears to have been suggesting ad valorem for large liquidations where the liquidator would make a windfall gain. Liquidators might therefore lose on both the swings and the roundabouts. This situation was obliquely acknowledged by Black $\mathbf{J}$ in the determination of the liquidator's actual remuneration in $S a k r,{ }^{154}$ following the Court of Appeal's judgment relating to the basis of the remuneration calculation.

There is a further dimension to the 'liquidator as gatekeeper' concept. The statutory EXAD report submitted at the conclusion of the liquidation takes time and costs the liquidator money to prepare. There is no point in requiring liquidators to incur the cost of breach reporting if ASIC does not act in response. If the liquidators are the ones primarily tasked to bring actions, ASIC should be reporting information about suspected breaches to the liquidator, rather than the other way around. ASIC obtains complaint information from members of the public and, in 2016-2017, received about 9,000 complaints. ${ }^{155}$

In terms of enforcement and recovery actions, it makes sense that whoever has the power to act is adequately funded to ensure they can fulfil their responsibilities properly. It does not make sense to squabble over who pays for it, as though the costs could be quarantined and not passed on. In the end, enforcement costs are always socialised, whether that enforcement is carried out by liquidators, by ASIC or by another agency. The costs of government agencies are borne by taxpayers. As discussed above, liquidators can be paid from a number of sources: from specific funding provided by ASIC or the Department of Employment; paid for out of the assets of the failed company, meaning less money for its creditors; or from cross-subsidisation from profitable liquidation engagements, meaning less money for their creditors. Directly or indirectly, society meets these costs. The economy is impacted by nonenforcement in relation to wrongdoing, through unfair competition in the market, unpaid taxes and superannuation, and additional support for FEG.

\footnotetext{
${ }^{154}$ See above n 125, [31]. 'I should note, however, that in some cases and possibly in this case, the amount of remuneration ultimately recoverable by a liquidator on a time basis, after deducting the costs of leading adequate evidence to establish it, may be less than the amount that may have been allowed on a percentage basis on the basis of less detailed evidence.'

155 ASIC, Annual Report 2016 - 2017, 4.
} 
ASIC's current level of enforcement is inadequate. This conclusion can be justified by comparing the numbers of reports of wrongdoing sent by external administrators to ASIC with the number of actions apparently taken by ASIC. ${ }^{156}$ Wrongdoers would be emboldened, rather than discouraged, to read of the five year disqualification of a director found by ASIC to have, in relation to 12 companies:

improperly used his corporate position by causing his companies to make loan repayments to related companies ahead of third party creditors whilst they were in financial difficulty;

failed to prevent some of the companies from trading whilst insolvent;

failed to ensure that proper financial records were kept;

failed to assist the liquidators of the companies after the companies had been wound up;

failed to exercise his duties as a director with due care and diligence; and

lacked the skills and expertise to manage the companies. ${ }^{157}$

More concerning still is the accompanying press release statement of ASIC Deputy Chair Peter Kell:

ASIC is extremely vigilant when it comes to protecting small businesses and will take firm action to protect creditors, consumers and investors from directors who fail to manage companies to the standards imposed by the law.

The maximum banning period imposed reflects the number of failed companies involved and the poor manner in which those companies were managed.

This statement might appear to suggest that ASIC was doing as much as possible in relation to this individual. That is not the case. ASIC could have brought civil penalty action or even criminal action in relation to the directors' duty breaches and the insolvent trading breach. There are also criminal sanctions for failing to assist the liquidator and keep proper financial records. Indeed, a failure to have proper financial records creates a conclusive presumption of insolvency, overcoming the greatest hurdle to an insolvent trading prosecution. Yet none of this was attempted. This response appears to typify ASIC's approach. ${ }^{158}$

\section{B Recommendations}

The following discussion contains a number of linked recommendations to enhance enforcement, ${ }^{159}$ and in doing so, reduce reliance on the safely net pot and increase the amounts in the general creditor and revenue pots. The threads joining them are money,

\footnotetext{
156 ASIC Report 558, above n 10, [41] indicates that there were 18,734 alleged breaches for the year 2016-17. Compare this with the half-year results in ASIC, Report 536 ASIC enforcement outcomes: January to June 2017, August 2017, table 6, which lists 'actions against directors: 2 criminal, 1 civil and 1 administrative; insolvency: 1 civil'. Unfortunately the report provides no details as to the nature of these matters. ${ }^{157}$ ASIC, 'ASIC disqualifies director from managing companies for maximum five year'. Media release 17 360MR, 27 October 2017, at http://asic.gov.au/about-asic/media-centre/find-a-media-release/2017-releases/17360mr-asic-disqualifies-director-from-managing-companies-for-maximum-five-year-period/

158 Above $n 156$ and accompanying text.

${ }^{159}$ In terms of improving enforcement, note also the government's adoption as policy of the Director Identification Number (DIN): The Hon Kelly O’Dwyer, 'A comprehensive package of reforms to address illegal phoenixing' (Media Release, 12 September 2017) ('Government Illegal Phoenixing Package'). In January 2018, the government also released an exposure draft of legislation, inter alia to improve the Single Touch Payroll system of tax liability reporting: Treasury Laws Amendment (Taxation And Superannuation Guarantee Integrity Measures) Bill 2018.
} 
motivation, power and information. If the present system of liquidator appointment is to remain, more must be done by ASIC to recognise the role of liquidators as valuable allies, providing them with additional information to assist their cases and funding to bring them. Suggestions to improve the sharing of information with liquidators is noted further below.

\section{A Government Funded Liquidator}

Funding for enforcement should be decided on the basis of who can investigate and prosecute wrongdoers in deliberate company failures most efficiently and effectively. The government appears to have a choice - either trust liquidators, with appropriate supervision, to be the primary enforcement agents in relation to insolvency-related misconduct, or else bring the function in-house in some way. If the government decides it cannot trust private profession liquidators to act independently, especially in small liquidations, it should consider either creating a pool of private practice liquidators as recommended by the Productivity Commission or establishing a 'government liquidator', ${ }^{160}$ similar to the Official Assignee in New Zealand. ${ }^{161}$ This model is also followed in Australia for bankruptcies where there is no registered trustee appointed. ${ }^{162}$

There are two main justifications for government intervention in small insolvencies. The first is to overcome the perception of inadequate performance on the part of liquidators, whether due to collusion with wrongdoers or lack of effort, justified or otherwise. The second is to deal with abandoned companies. A government funded pool of private-practice liquidators may well deal with the first but it is difficult to see how it would deal with the second.

Providing a pool of liquidators, allocated on a 'first cab off the rank' process, may have value if it helps to nullify the tension described above between ASIC and liquidators. The Productivity Commission was in favour of a pool of insolvency providers for small 'streamlined' liquidations for two reasons. ${ }^{163}$ First, the fees could be set via a tender process to "preserve competition and allow innovation on the basis of fees (hourly, fixed, event based or a hybrid form).' This would ensure that there are adequate numbers of available practitioners but that none were profiting excessively from this work. ${ }^{164}$ The second reason for the pool was to support practitioner independence. ${ }^{165}$ However, the report did not state how the 'next cab off the rank' system would reconcile with the tender process. In addition, there is no indication of how liquidator excellence would be encouraged if reputations become irrelevant because jobs were allocated via the cab rank. If the government does decide to pursue the cab rank idea as Treasury has suggested it might, ${ }^{166}$ a method of ensuring that there is sufficient funding for all the required liquidators is vital to such a scheme's success. ${ }^{167}$

\footnotetext{
${ }^{160}$ Treasury has sought feedback on this idea: Australian Government, Treasury, Combatting Illegal Phoenixing, ('Combatting Illegal Phoenixing'), September 2017, 29.

${ }^{161} \mathrm{http}$ ://www.insolvency.govt.nz/cms/financial-trouble/business-debt/company-liquidation/liquidationfreqently-asked-questions/multipagedocument_all_pages

${ }^{162}$ Bankruptcy Act 1966 (Cth) s 18. This is the Official Trustee in Bankruptcy, administered by the Australian Financial Security Authority ('AFSA'). See https://www.afsa.gov.au/practitioner/trustees/official-trustee-inbankruptcy

${ }^{163}$ Productivity Commission Business Set Up Report, above n 70, 407-8.

164 Ibid 407.

165 Ibid 408.

166 Combatting Illegal Phoenixing, above n 160, 26-29.

167 The Productivity Commission recognised funding issues, above n 70, at 410-412. Where Assetless Administration Funding is reallocated to a 'cab rank' system, the Productivity Commission recommended it be renamed the Public Interest Administration Fund, to recognise the protective role of the liquidators' work. Ibid.
} 
A government liquidator as a government agency could be effective in relation to abandoned companies but given their volume, there would need to be guidelines to select appropriate cases. Proper data analysis of potential directors and company registrations, considered further below, could lead the government towards those who walk away from their companies repeatedly. Where ASIC proposes to deregister a company for failure to submit documents or pay fees, ${ }^{168}$ the companies formerly run by repeat offenders could qualify for further scrutiny. The cost of running this sort of service could be justified by the recovery of unpaid taxes and superannuation, and reduced reliance on FEG. In addition, increased enforcement activity has the capacity to result in the deterrence of the 'dump and run' strategy, in turn benefiting both revenue and general creditors. The downsides of a government liquidator are that it may lack the sort of efficiency, expertise and costcompetitiveness found in the private sector, and that there is arguably a conflict of interest between the government as both liquidator and significant creditor.

\section{Widening the Pool of Enforcers and Improve Information Flows}

This discussion will focus on other parties who could assist with insolvency-related enforcement, justifying the allocation of money towards their work and improved access to information and cooperation between them. As Part III showed, both the ATO and the $\mathrm{FWO}^{169}$ have powers to bring actions relating to conduct which takes place around the time of a company's insolvency. The new Protecting Vulnerable Workers laws extend the FWO's jurisdiction well beyond the parties that either ASIC or the ATO currently reach.

It was also discussed above that the ATO has considerable powers as a revenue regulator as well as significant exposure to losses from insolvency as a creditor. Information gathered by either ASIC or the ATO can assist both regulators in discharging their functions and recovering tax revenue. It is therefore pleasing to see that ASIC has recently had its powers to share confidential information with the ATO enhanced. ${ }^{170}$ However, there needs to be greater sharing of non-confidential information in both directions. Three examples are particularly relevant in the insolvency context. First, an application to the ATO by those seeking an Australian Business Number (ABN) for their company requires 'associate details', including the name, date of birth, position held and tax file number of all Australian resident directors. At present, the ATO does consult with ASIC regarding company ABN applications but only to check the validity of the Australian Company Number (ACN). It does not check whether any associates of the company are disqualified from managing corporations or what other companies those associates own or control. This is an oversight that should be addressed.

Second, ASIC currently provides the ATO-administered Australian Business Register (ABR) with information about companies entering external administration or being deregistered for a variety of reasons, including failure to return documents and pay fees. This prompts the ABR to cancel the company's $A B N$. If the ABR discovers that the people associated with a cancelled ABN are seeking a new ABN, it should alert ASIC to this activity. This would assist ASIC in determining whether those associated with an abandoned company were seeking to create a new company that plans to trade and therefore to expose creditors to the possibility of unrecoverable debts.

\footnotetext{
168 Above n 14 and accompanying text.

169 Above n 102 and accompanying text.

${ }^{170}$ Section 127(2A)(g) was added to the ASIC Act by Treasury Laws Amendment (2017 Measures No 1) Act 2017 (Cth).
} 
Third, there needs to be better sharing by ASIC with the FWO and ATO of superannuation non-compliance information. ${ }^{171}$ In addition to complaints from employees, superannuation non-compliance is detected and reported to the ATO through third party referrals. As noted above, ASIC does have this information through EXAD reporting. However, the ATO submission to the Senate Economics References Committee inquiry on non-compliance with the superannuation guarantee did not provide a figure for ASIC referrals. ${ }^{172}$ Rather than the FWO referring complaints about unpaid superannuation to the ATO, they should investigate and take action directly where they have jurisdiction. ${ }^{173}$

There is also a notable lack of involvement by professional bodies other than ARITA in the policy development and enforcement domains relating to insolvency. While there is a heavy emphasis by ASIC on liquidators acting professionally and charging appropriate remuneration, ${ }^{174}$ there are no references to similar requirements of accountants, tax advisors or lawyers offering insolvency advice. Some of the most notorious phoenix activity advisors have been lawyers or accountants. ${ }^{175}$ Rather than concentrating on liquidators as the sole 'gatekeepers' of proper conduct during insolvency, ASIC should leverage the accreditation requirements of the legal and accounting professions as a means of deterring and punishing advice leading to director misconduct. ${ }^{176}$

\section{Money for Fraud Prevention and Detection Systems}

There are many ways in which misconduct relating to insolvency could be deterred, disrupted or detected if it occurs. ${ }^{177}$ Only a few examples are mentioned here; these are ones that require significant money to be spent, justified on the basis that these costs will either save further expenditure on enforcement or safety nets, or will reduce the loss of revenue.

ASIC currently charges all parties to access much of the information on their registers. This includes liquidators undertaking insolvency engagements as ASIC's 'gatekeepers'. These documents include searches of directors and their associated companies. ${ }^{178}$ It seems contradictory to expect liquidators to perform this work using the insolvent company's limited funds, and simultaneously for ASIC to charge them for the documents that are essential to perform it. Recall that the costs of the liquidation take priority over payments to employees and unsecured creditors. These search charges therefore involve funds going to ASIC from the DE administering FEG and from the ATO as an unsecured creditor.

In addition, ASIC's information systems should be overhauled or augmented to allow information to be more readily available for searching and for detection by regulators. At

\footnotetext{
171 This was also a recommendation of the Senate Economics References Committee, Parliament of Australia, 'I just want to be paid': Insolvency in the Australian Construction Industry (2015), recommendation 5, [3.72].

${ }_{172}$ Australian Taxation Office, Submission No 6 to Senate Economics References Committee, Inquiry into Superannuation Guarantee Non-payment, 2016-17, [49]-[53]. It noted that in 2015-16, the Fair Work Ombudsman (FWO) made 2,405 referrals, with 73 from super funds, 651 community referrals, 70 internal ATO referrals and 57 from 'other'.

${ }^{173}$ See above n 100 and accompanying text.

${ }^{174}$ See for example, ASIC, 'Proposed Industry Funding Model for ASIC: Supporting Attachment', above n 147, [107]; also, ASIC, 2017-18 ASIC business plan summary by sector: Insolvency practitioners, 2.

175 Above $n 151$ and accompanying text.

${ }^{176}$ Legal Profession Uniform Law Australian Solicitors' Conduct Rules 2015; Accounting Professional and Ethical Standards Board, APES 110 Code of Ethics for Professional Accountants, December 2010.

${ }^{177}$ Helen Anderson, Ian Ramsay, Michelle Welsh and Jasper Hedges, Phoenix Activity: Recommendations on Detection, Disruption and Enforcement (Research Report, Centre for Corporate Law and Securities Regulation, The University of Melbourne, February 2017).

178 See http://asic.gov.au/online-services/search-asics-registers/
} 
present, it is not possible for a person to construct the history of a director and their present and previous directorships without either paying an information bureau or credit rating agency to undertake the search or spending considerable time and money piecing the picture together, one search at a time, themselves. This type of information allows potential employees, lenders and customers of companies to avoid those whose management have a history of insolvency-related misconduct. Improving access to information could result in a saving on enforcement action and avoid additional losses particularly to the general creditor pot and the safety net pot. Therefore, money should be invested in an integrated search tool that allows a person to obtain this information easily and cheaply.

Given federal budgetary concerns, it may be politically unpalatable to suggest that all registry search information is free, but doing so would be consistent with the approach being taken to this issue in the UK. ${ }^{179}$ According to UK Secretary of State for Business, Innovation and Skills, the Rt Hon Dr Vince Cable,

[t]he government firmly believes that the best way to maximise the value to the UK economy of the information which Companies House holds, is for it to be available as open data. By making its data freely available and free of charge, Companies House is making the UK a more transparent, efficient and effective place to do business. ${ }^{180}$

A replacement source of funding would make this sort of proposal more appealing. The earlier discussion on the industry cost recovery model opposed a levy on liquidators; however, a levy on companies does not suffer from the same objections. The government favours cost recovery levies that are imposed regulated populations. ${ }^{181}$ As noted above, there is already such a levy proposed on small proprietary companies, to be met from an increase in their annual review fee, ${ }^{182}$ with more significant amounts levied on larger companies. ${ }^{183}$ Given that it is the insolvent company which causes losses to the general creditor, revenue and safety net pots and which may generates the need for enforcement action, it is justifiable that all companies pay a reasonable levy. They enjoy the privilege of being separate legal entities, allowing for the protection of their shareholders who benefit from limited liability. Undoubtedly, levy costs would be socialised by the companies through the cost of their products and services. However, because there are just under 2.5 million companies in Australia, ${ }^{184}$ providing billions of dollars worth of goods and services, socialising these costs would be barely perceptible.

\section{CONCLUSION}

\footnotetext{
179 See UK Companies House, 'Launch of the New Companies House Public Beta Service' (News Story, 22 June 2015): '[i]n line with the government's commitment to free data, Companies House is pleased to announce that all public digital data held on the UK register of companies is now accessible free of charge, on its new public beta search service. This provides access to over 170 million digital records on companies and directors including financial accounts, company filings and details on directors and secretaries throughout the life of the company.'

${ }^{180}$ UK Department for Business, Innovation \& Skills, 'Free Companies House Data to Boost UK Economy' (Press Release, 15 July 2014).

${ }^{181}$ Australian Government, Department of Finance, Australian Government Cost Recovery Guidelines, Resource Management Guide No. 304, July 2014 - Third edition, 2.

182 Above $n 149$ and accompanying text.

${ }^{183}$ Ibid [92] (large proprietary companies); [91] (unlisted public companies); and [86] - [88] (listed public companies).

184 Ibid, table 10.
} 
Some creditors will inevitably lose money as a result of corporate insolvency, and this paper has not suggested otherwise. Nonetheless, there are ways of dealing with the various pots of money touched by insolvency that maximises the returns to creditors and minimises reliance on various forms of government support. While it is impossible to accurately estimate either the current losses caused by insolvency-related wrongdoing or how much of this could be saved by a new approach, better policies can be developed and improved outcomes for creditors and the government can arguably be achieved by looking at all the pots of money at the same time.

In terms of enforcement and recovery actions, whoever has the power should be adequately funded to ensure they can fulfil their responsibilities properly. Much emphasis is placed by ASIC on liquidators as gatekeepers, so imposing a levy on liquidators is the very place at which no further costs should be imposed. Money paid by liquidators to ASIC as an incentive to perform their roles more effectively is likely to have the opposite effect. Rather, placing a levy on the companies that are registered makes more sense. These are the ones causing losses through their insolvency, whether they enter liquidation or are abandoned. Because the costs of the levy on companies can be socialised widely, these levies could easily absorb the $\$ 10.196$ million currently imposed on registered liquidators. ${ }^{185}$

To begin with, there should be a statutory clarification of the liquidator enforcement role. Once this has been done, attention should be paid to a review of their funding and the information that is supplied to them. The FEGRP exemplifies the sorts of recoveries that can be achieved where a self-interested creditor provides funding for liquidators. If the government is unwilling to recast the role of liquidators because it does not believe that liquidators can act with sufficient integrity and independence, it should consider a government liquidator or a government allocated panel of private liquidators. Maintaining the current antagonism is counter-productive.

This is not to say that insolvency related enforcement is the exclusive domain of ASIC and liquidators. The ATO has an important role to play in protecting the revenue through its own enforcement and in providing funding to liquidators for recovery. These sorts of activities can achieve both specific and general deterrence of insolvency-related wrongdoing, filling an apparent enforcement gap left by ASIC. The ATO should look to bring more actions under the Crimes (Taxation Offences) Act, which is highly suitable for insolvency-related defaults in a way that other anti-avoidance laws are not. Better information sharing amongst the relevant regulators will underpin the success of the ATO as a valuable insolvency enforcement agency.

One area currently dominated by the ATO is superannuation recovery yet in this area, the contrary argument can be made. The FWO has both extensive jurisdiction in relation to superannuation governed by modern awards and enterprise agreements, as well as growing recovery powers, but is reluctant to take on superannuation enforcement. This is regrettable given their excellent track record against companies failing to pay other employee entitlements, in addition to their actions against accessories 'knowingly concerned' in the company's breach. ${ }^{186}$ These powers have recently been extended to cover holding companies and franchisors in certain circumstances and are superior to the recovery powers of the ATO

\footnotetext{
185 Above n 143, [109], table 9.

${ }^{186}$ A recent example is Fair Work Ombudsman v NSH North Pty Ltd trading as New Shanghai Charlestown [2017] FCA 1301 where an HR manager who falsified payroll records to deceive the FWO was penalised for her actions.
} 
in relation to superannuation. While unpaid superannuation has no immediate effect on either employees or the government because it is not covered by FEG, it must be remembered that those employees are likely to receive significantly less when they retire and will therefore have a greater reliance on the government-funded aged pension.

The losses caused to employees and general creditors by abandoned companies seem to fall between the cracks. They are neither the concern of liquidators nor of ASIC except in a very limited way. To the extent that wrongdoing by those who abandon companies is undetected, unprosecuted and therefore undeterred, society as a whole is the loser. There is a strong argument, therefore, for a means of looking at these companies and working to prevent repeated company abandonment by the same offenders. Improvements are not costless. It's all about the money, and where it is most effectively spent. 